\title{
DHODH wt Allele
}

National Cancer Institute

\section{Source}

National Cancer Institute. DHODH wt Allele. NCI Thesaurus. Code C50876.

Human DHODH wild-type allele is located within $16 q 22$ and is approximately $16 \mathrm{~kb}$ in length. This allele, which encodes dihydroorotate dehydrogenase, mitochondrial protein, is involved in de novo pyrimidine biosynthesis. 